
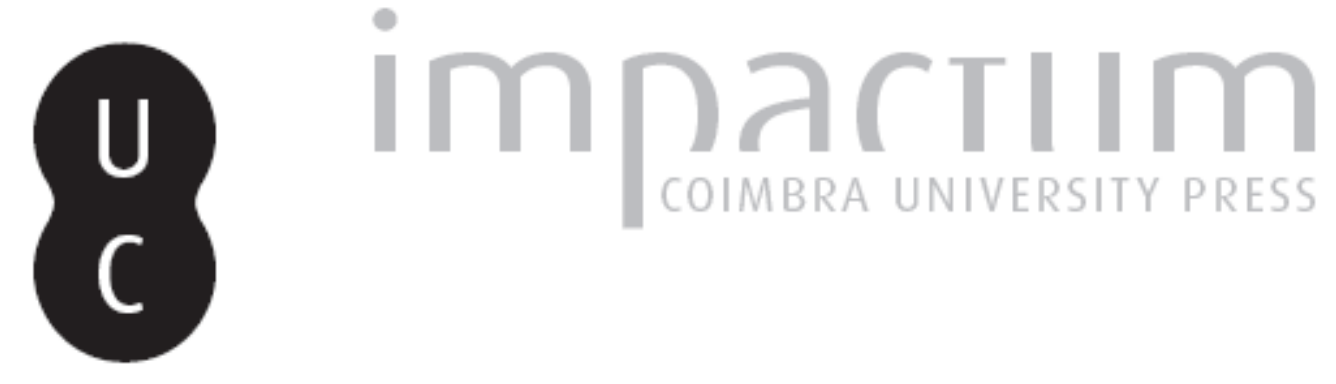
Mundus novus, novus homo: cartografias do imaginário e do Outro no Novo Mundo
(séc. XVI-XVII)

Autor(es): $\quad$ Costa, Luís Manuel Neves

Publicado por: Centro de História da Sociedade e da Cultura

URL persistente:

URI:http://hdl.handle.net/10316.2/39391

DOI:

DOI:http://dx.doi.org/10.14195/1645-2259_13_9

Accessed : $\quad$ 26-Apr-2023 00:14:37

A navegação consulta e descarregamento dos títulos inseridos nas Bibliotecas Digitais UC Digitalis, UC Pombalina e UC Impactum, pressupõem a aceitação plena e sem reservas dos Termos e Condições de Uso destas Bibliotecas Digitais, disponíveis em https://digitalis.uc.pt/pt-pt/termos.

Conforme exposto nos referidos Termos e Condições de Uso, o descarregamento de títulos de acesso restrito requer uma licença válida de autorização devendo o utilizador aceder ao(s) documento(s) a partir de um endereço de IP da instituição detentora da supramencionada licença.

Ao utilizador é apenas permitido o descarregamento para uso pessoal, pelo que o emprego do(s) título(s) descarregado(s) para outro fim, designadamente comercial, carece de autorização do respetivo autor ou editor da obra.

Na medida em que todas as obras da UC Digitalis se encontram protegidas pelo Código do Direito de Autor e Direitos Conexos e demais legislação aplicável, toda a cópia, parcial ou total, deste documento, nos casos em que é legalmente admitida, deverá conter ou fazer-se acompanhar por este aviso.

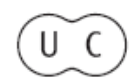



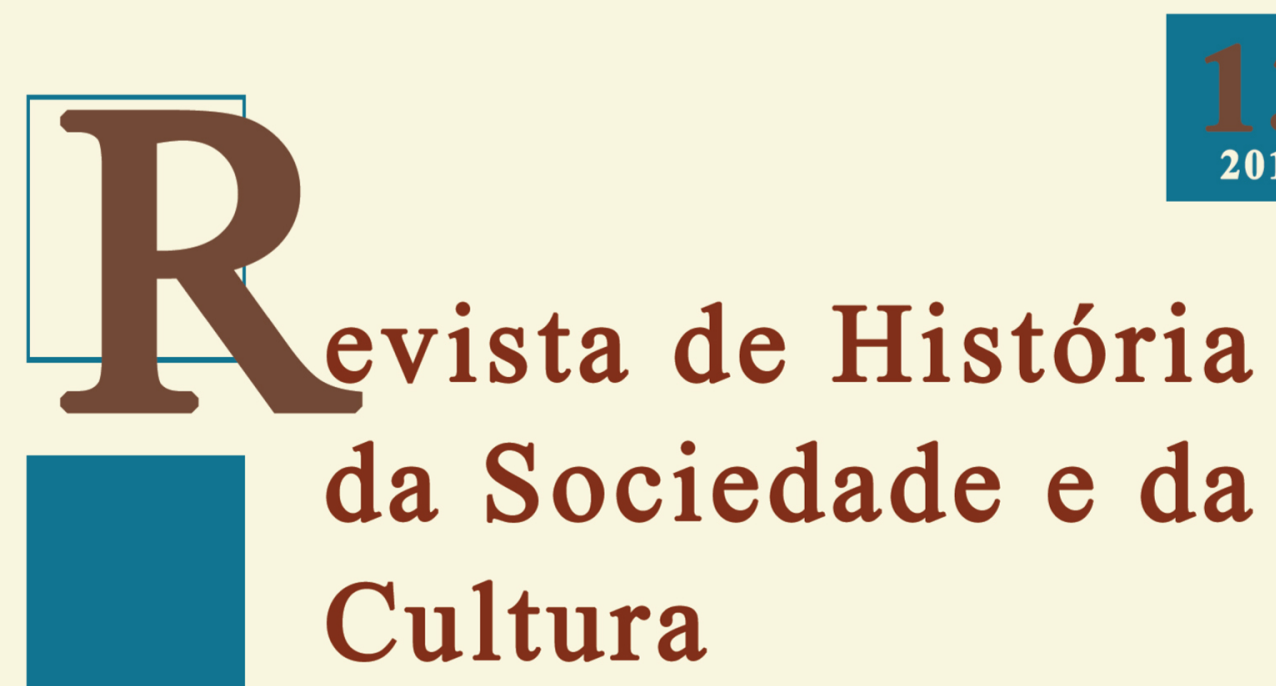

2013

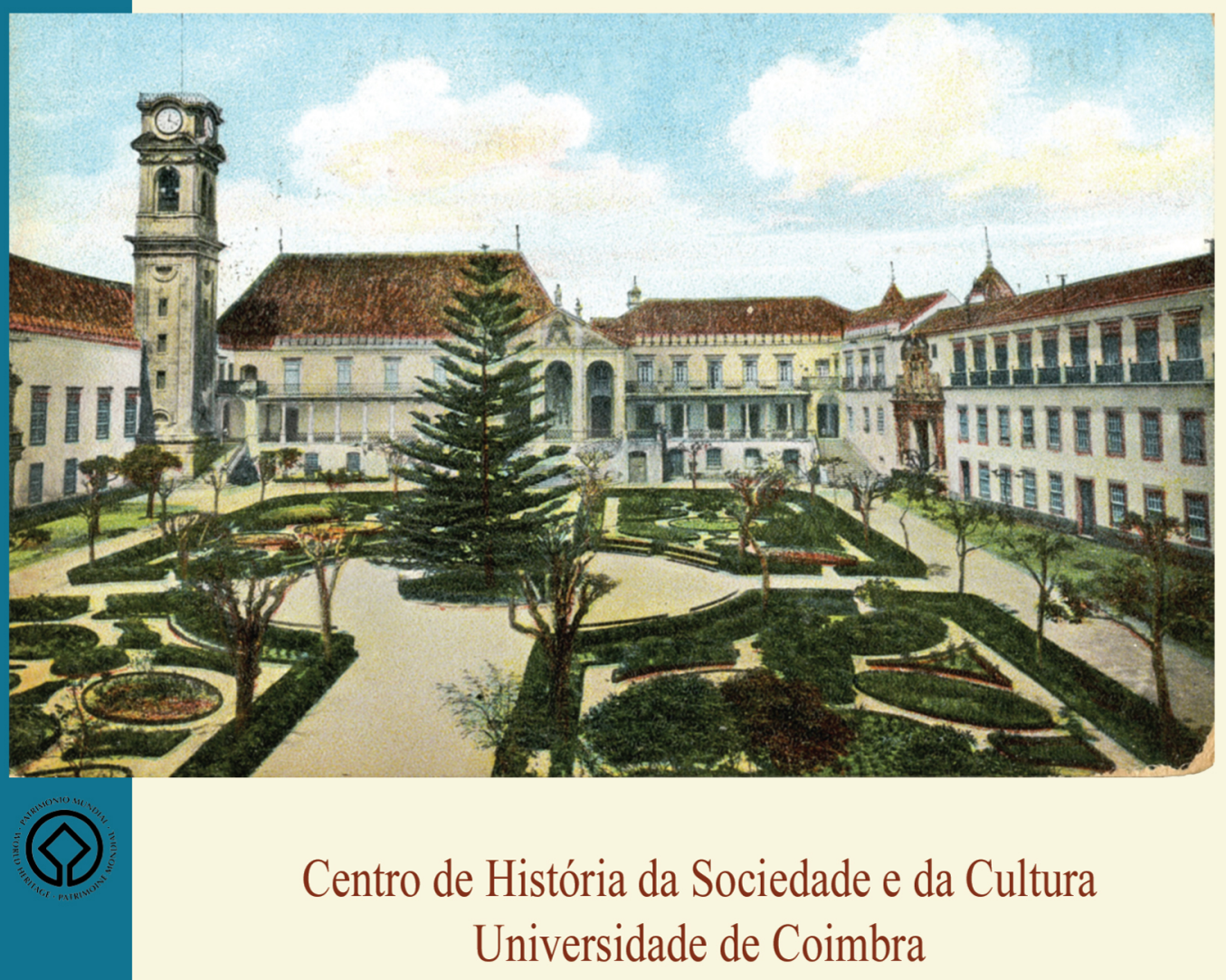

Coimbra 


\title{
Mundus Novus, Novus Homo. Cartografias do imaginário e do Outro no Novo Mundo (séc. XVI-XVII)
}

\author{
Luís Manuel Neves Costa \\ Universidade de Coimbra - Faculdade de Ciências e Tecnologia \\ Departamento de Ciências da Vida / Antropologia \\ CRIA - Centro em Rede de Investigação em Antropologia \\ Doutorando em Antropologia (especialidade de Antropologia Social e Cultural) \\ luismncosta@gmail.com \\ Texto recebido em /Text submitted on: 08/02/2013 \\ Texto aprovado em /Text approved on: 06/10/2013
}

\section{Resumo/Abstract:}

O Novo Mundo foi imaginado e interpretado com base em referenciais clássicos e medievais. O imaginário foi o primeiro elemento organizador e condutor para a apreensão e compreensão da nova realidade encontrada. A descoberta da América foi interpretada inicialmente como a descoberta da Utopia dos pensadores do séc. XVI, o novo espaço no qual seria possível localizar os projectos dos humanistas e renascentistas. O novo espaço já era povoado por homens com traços de monstruosidade, segundo as descrições dos primeiros exploradores e cronistas e as representações da iconografia da época. Entre os autores eruditos foi profundamente debatida a problemática da origem e da natureza do outro - o "índio do ocidente". Toda a argumentação, assente fundamentalmente em bases teológicas e bíblicas, chegou a ser mobilizada tendo em vista proveitos políticos e estratégicos para a coroa espanhola. Este artigo aborda a construção e o entendimento do Outro, num entrecruzamento entre a Antropologia e a História.

The New World was imagined and interpreted based on classical and medieval references. The imaginary was the first organizing element and the driver for the understanding and comprehension of the newly found reality. The discovery of America was initially interpreted as the discovery of the Utopia for the $16^{\text {th }}$ Century thinkers, a new space where it would be possible to find renaissance and humanism projects. This new space was already inhabited by men with traits of monstrosity, according to the descriptions of the early explorers and chroniclers and the representations of the iconography of the time. Among scholars, the origin and nature of the other - the "Indian of the West" - is deeply debated. This debate, primarily based on theological and biblical bases, was mobilized in order that the Spanish crown would profit politically and strategically. This article discusses the construction and understanding of the Other, a crossing between Anthropology and History.

Palavras chave/Keywords:

Novo Mundo; América; Imaginário; Monstrificação do Outro.

New World; America; Imaginary; The Other as a monstrosity. 


\section{Introdução}

Chegar ao Novo Mundo foi um acaso. Cristóvão Colombo traçou um plano para atingir a Ásia, concretizando-o a 12 de Outubro de 1492. O navegador manteve-se convencido desse feito durante toda a sua vida, devido ao conhecimento inexistente na Europa sobre as costas Asiáticas. Em 1506, a designação de Novo Mundo é a que melhor caracteriza as terras que se vão desvendando e desbravando.

A primeira ideia de América construiu-se com a intensidade das imagens que precederam o seu encontro. Os espaços da invenção convergiram desde múltiplos pontos.

O Novo Mundo, espaço incógnito para Espanha, emergiu como um território sobre o qual foram lançados diversos olhares, que oscilaram entre o mítico e o fantástico. A noção de "Novo Mundo" como um espaço simbólico e conceptual e não, simplesmente, físico e territorial. A visão renascentista de paraíso terrestre foi materializada na América, fruto de toda a construção cultural que vinha desde a Antiguidade Clássica e atravessou a época medieval. A América emergia, então, como a desejada Utopia.

Para os primeiros conquistadores e colonizadores, o modo de referenciar toda a novidade encontrada foi descrevê-la e relatá-la com base na analogia com o mundo até então conhecido. Quem descreve e conta algo, fá-lo desde a sua linguagem, com as suas palavras tendo por base um quadro conceptual. Ao descreverem o que encontraram, fizeram-no partindo da esfera dos seus saberes e da sua cultura, tendo, portanto, como ponto de partida para revelar o Novo Mundo, a experiência construída e acumulada no Velho Mundo. Os padrões de vida europeus (religiosos, sociais, culturais) marcaram e condicionaram o entendimento de quem aportou nos novos territórios.

O imaginário europeu viajou até além-mar, promovendo a invenção de um novo mundo. A descoberta do Quarto Continente é subsequente à sua invenção, quando o europeu levantou novas questões e constatou que o seu conhecimento era desadequado, promovendo a experiência e a exploração racional do mundo. A fantasia, o fantástico, o maravilhoso cederam lugar à descoberta, à exploração, ao conhecimento. A Viagem marcava o nascimento da Modernidade. 
A Espanha procurou no Novo Mundo a "confirmação" da existência do maravilhoso medieval, com os seus seres imaginários, fruto de todo um repertório literário que vinha desde a Antiguidade. As múltiplas imagens, que pretendiam representar o outro, dão conta da adaptação de um imaginário colectivo, europeu, que é mobilizado para a apreensão e concepção de uma novo mundo, moldando-se à realidade encontrada. A imagem do outro começou por ser uma imagem estereotipada através da monstruosidade, mais tarde, o europeu ao chamar índio ao nativo conferiu-lhe uma nova identidade.

Este artigo pretende abordar, entrecruzando a história com a antropologia, a visão e entendimento do outro a partir do imaginário social e cultural dos europeus que chegaram ao Novo Mundo, encarando-o como o monstro, a besta, descrita nos relatos dos antigos viajantes ou autores clássicos. Porém, o debate sobre o outro, também foi empreendido por múltiplos autores eruditos, que discutiam e dissertavam sobre a origem e natureza do "índio do ocidente". Importa analisar a concepção e entendimento de um "admirável mundo novo", em especial, sob olhar (eurocêntrico) sobre o outro desde o universo do imaginário acumulado, até às discussões teológicas sobre o "indio do ocidente".

\section{1. "Cartografias" do Imaginário: processos e imagens na descoberta de um Novo Mundo}

Os descobrimentos remetem-nos para toda uma esfera de significações inerentes à época em que ocorreram. A abordagem do imaginário europeu do século XV-XVI leva-nos a perceber o novo território, habitado por novos povos, como espaço de transformação num "Novo Mundo", onde os colonizadores deveriam implementar os padrões básicos de vida social e cultural da Europa. Impunha-se a construção de um Novo Mundo, à semelhança do Velho Mundo.

\subsection{Imaginário Medieval em trânsito: bagagem da viagem às Índias}

Colombo, ao chegar às novas terras, pensava ter atingido o Paraíso terrestre, fruto da crença medieval europeia da sua existência. Olhar o Novo 
Mundo implicava o mobilizar de referências do Velho Mundo, assentes em mitologias, lendas e histórias.

A "descoberta" de Colombo vem confirmar e dar sentido a todo um manancial cultural imaginário vigente, como o da existência do Paraíso Terrestre ou o da existência do Eldorado. A fronteira entre o real e o imaginário era muito ténue. Tudo o que era real (o indígena, as florestas, os animais, etc.) reforçava as visões antigas ou reconfigura-se e originava novas visões imaginárias, novas representações sociais. Estas novas terras, ponto de encontro de paz, de cenários idílicos, de inocência, configuraram-se como o local em tempos habitado por Adão e Eva.

Filósofos da Antiguidade (Aristóteles e Séneca), geógrafos clássicos (Ptolomeu), cientistas árabes (Averroes e Alfragano) e os textos, As Viagens de Marco Polo (1300), Imago Mundi (1410) de Petrus Alliacus (Pierre d'Ailly) e a Historia rerum ubique gestarum (1461) de Eneas Silvio Piccolomini, para além das Sagradas Escrituras, influenciaram de forma considerável o projecto de Colombo ${ }^{1}$. Todas estas obras clássicas detêm como denominador comum a considerável dimensão da esfera do imaginário. Cristóvão Colombo, como tantos outros navegadores, ao partir para as suas viagens, transportou toda uma bagagem de informações de livros de viagens, de mitos, de crenças que vinham desde a Antiguidade e povoavam a mentalidade da época. A “crença mais surpreendente de Colombo é de origem cristã: refere-se ao paraíso Terrestre"2 apesar de se ter orientado pela concepção do Imago Mundi de Pierre d'Ailly.

O facto dos navegadores terem encontrado sereias, antípodas ${ }^{3}$, cinocéfa$\operatorname{los}^{4}$, ciclopes ${ }^{5}$ e outras tantas criaturas monstruosas, quando viajavam pelo desconhecido, reflecte bem o poder do imaginário sobre os aventureiros. Todo o imaginário europeu foi projectado sobre a diferente realidade que encontravam. Tudo o que era estranho foi conotado com imagens familiares,

1 GONZÁLEZ BOIXO, José Carlos - La Génesis del Descubrimiento y la Nueva Imago Mundi, ségun los cronistas de Indias. Rev. Destiempos. 3 (14) (2008) 15-24.

2 TODOROV, Tzevetan - A conquista da América: a questão do outro. Lisboa: Litoral, 1990, p. 21.

3 Criaturas com os pés virados para trás.

4 Criaturas com corpo humano e cabeça de cachorro, que se alimentavam de carne humana.

5 Monstro que se caracterizava por ter um único olho no meio da testa. 
podendo desse modo entender e apreender a novidade do espaço e das suas criaturas.

Nesta linha, compreende-se a associação dos novos territórios com a imagem do Paraíso Terrestre. De igual modo, se existia o Paraíso decerto que também existiam elementos conotados com o Demónio (os insectos, certos animais, o calor intenso, os costumes dos indígenas). $\mathrm{O}$ indígena estava bem presente no imaginário dos europeus, enquanto homens selvagens que habitavam livremente nas florestas, que viviam e conviviam com base nos seus instintos e rituais (danças, nudez, práticas sexuais, adorando as suas divindades), opondo-se aos princípios europeus cristãos, o que se configurava em práticas demoníacas.

Todo o imaginário remete-nos para a esfera do simbólico da expressão humana, enquanto esfera isenta de toda a racionalidade inerente à época. Todo o imaginário confere sentido e valor à aventura humana, projectando desejos mediante um todo simbólico.

Nas suas viagens, os europeus transportaram todo o referencial do imaginário medieval, recriando a tradição cultural cristã do velho mundo no novo espaço além-Atlântico. Juan de Castellanos nas Elegías [1587], que dedica a Cristóvão Colombo ${ }^{6}$, anuncia que "Al Occidente van encaminadas las naves inventoras de regiones". A "quarta região" do mundo "inventa est per Vespuccio" - esclarece Waldseemüller na edição do Quattuor Americi Navegationes em 1507. Para cronistas e poetas, a América não se descobre: inventa-se.

A imaginação é mais importante que o conhecimento. A América foi inventada antes de ser descoberta ${ }^{7}$, pois o europeu, ao construir o Novo Mundo, representou o seu sonho, o seu desejo, o seu imaginário a partir de toda a sua bagagem cultural, fruto das suas vivências e aprendizagens na Europa,

"[...] os descobrimentos representavam uma grande oportunidade para os povos ibéricos concretizarem seus sonhos, construindo, reproduzindo e assimilando na América todo processo cultural de que eram originários. O suporte económico, embora tenha favorecido a

${ }^{6}$ CASTELLANOS, Juan - Elegías de Varones Ilustres de Indias. Barcelona, Biblioteca de Autores Españoles: tomo IV, 1944 [1587].

7 O'GORMAN, Edmundo - A invenção da América. São Paulo: Unesp, 1992. 
realização dessa empresa, não explica os diversos significados que assumiu a conquista. As instituições religiosas e política se cristalizaram, penetrando fundo no quotidiano colonial. O passado criou raízes muito fundas principalmente onde os indígenas mantiveram parte de suas tradições, tornando-se um peso do qual ninguém de fato queria se libertar. [...] a empresa colonial surge não apenas como resultado de uma política económica, mas também como forma de expressão de uma estrutura mental."

A descoberta não permite a imaginação e fantasia sobre o que já existe e se encontra. Inventar é transformar a realidade, mobilizando a bagagem do imaginário que já se detém.

Mas o encontro da América por Espanha ocorreu a partir do encontro físico, transparecendo aquela como algo real e previamente existente (nesse sentido Espanha não a inventa porque já tinha existência anterior a 12 de Outubro de 1492, mas re-inventa-a) em que, para melhor a conhecer, imperou o mobilizar do imaginário, do sonho, do desejo, do mito, da utopia, da literatura.

O imaginário colectivo ocidental foi transportado para o território da América, levando aventuras dos livros de aventuras, cidades, catálogos de zoologia e botânica fantástica, lendas e tradições. Os primeiros tempos do Europeu na América, conduziram-no à impregnação e tentativa de colagem do seu imaginário à realidade encontrada e descrita,

"los españoles no tratan de adquirir nuevas nociones en América, sino más bien de verificar antiguas leyendas: las profecías del Antiguo Testamento, los mitos grecolatinos como la Atlántida y las Amazonas, las leyendas medie $\neg$ vales como el Reino del Padre Juan y la Fuente dejuvencia"".

AAmérica "no era otra cosa que el ideal de Europa. En ella se veía lo que el europeo quería que fuese Europa. Fue el modelo conforme al cual había que rehacer al mundo occidental" ${ }^{\prime \prime}$. A América é a utopia inventada pela

8 THEODORO, Janice - Descobrimentos e Colonização. São Paulo: Editora Ática, 1987, p. 13-14.

9 LÉVI-STRAUSS cit. por AINSA in AINSA, Fernando - Profecías del Encuentro. El Correo de la UNESCO. (Mayo, 1992) 12.

${ }^{10}$ ZEA, Leopoldo - América como conciencia. México: UNAM, 1972, p. 35. 
Europa, era o não lugar, era o u topos, pois tal como O'Gorman escreve "todo o descobrimento é um desejo, e todo o desejo uma necessidade. Inventamos o que descobrimos; descobrimos o que imaginamos. Nossa recompensa é o assombro"11. O Novo emerge como reflexo do Velho e constrói-se a partir das suas fantasias, podendo-se afirmar que a primeira visão da América foi a projecção de um mundo próprio, já conhecido.

\subsection{Mundo Novo: Utopia no Séc. XVI}

A utopia é por definição um espaço sem localização real. Espaço "imaginário", produto da criatividade humana, circunscrito a uma temporalidade definida. Se a utopia não tem um espaço de localização concreta, existe a ambição de a localizar algures. Deste modo, a descoberta do Novo Mundo veio permitir que o imaginário de diversos autores pudesse conceber aquele como um espaço possível onde localizar os seus projectos.

Os críticos da velha Europa situaram no novo continente o tipo de vida que ambicionavam para uma nova Europa. Não bastava a evasão, importava sim reconstruir o mundo no qual se sentiam insatisfeitos. Revelou-se imperativo estabelecer uma nova ordem (não a ordem da autoridade, assente na tradição, no tempo e na história), assente na liberdade do homem que poderia conduzir a um novo tipo de sociedade ${ }^{12}$.

O Novo Mundo, como local absolutamente ignoto para o homem europeu, passou a constituir-se como o local físico onde era possível realizar a Utopia, onde era possível sonhar com um mundo isento das misérias da realidade concreta, que traduzia uma frustração para com a civilização. Homens humanistas e renascentistas julgaram estarem perante a edificação de um mundo novo, aquando da imprevista descoberta de extensos territórios e novos povos, que tinham permanecido incontactáveis com o velho mundo e, como tal, não estavam contaminados com a decadência de valores vigentes na Europa de então, a necessitarem de uma profunda reforma.

${ }^{11}$ O'GORMAN, Edmundo - A invenção da América ..., cit., p. 59.

${ }^{12}$ ZEA, Leopoldo - América como..., cit. 
A obra de Thomas More, Utopia ${ }^{13}$, dá conta da formulação das interrogações fundamentais acerca dos valores e das normas vigentes na Europa da época. Mas que aconteceu com as utopias? Aquilo a que ingenuamente se chamava de "realidade" torna-se terrível e avassalador.

Como expressão máxima da re-construção, da re-estruturação, da re-elaboração e da representação do novo espaço à medida e imagem da cultura do velho continente, ocorre a destruição do espaço das populações pré-colombianas: as ruas e os mercados reconfiguram-se por novos traçados, pela edificação de igrejas e catedrais (símbolos da fé cristã), pela construção de cidades inteiras à imagem e semelhança da Europa. O desenho indígena foi substituído pelo traçado urbano "sofisticado" de modo a recrear o perfil e referencial europeu. A própria designação dos novos territórios com nomes da nação de origem, como a Nova Espanha, pretende traduzir a outra, a herdeira, a continuidade da tradição cultural que ficou do outro lado do oceano.

O colonizador Europeu empenhou-se em recrear símbolos e elementos que deixou para trás. Para o indígena a cultura europeia emerge enquanto uma imposição que vem de fora, é a exigência do colonizador que ele assume e integra para poder manter a sua vida.

Todorov ao escrever que "Colombo descobriu a América, mas não os americanos" ${ }^{14}$, expressa bem a representação de inferioridade do outro para o europeu. O outro só existia na medida das descrições produzidas por Colombo sobre a natureza, emergindo com indiferença aos olhos do navegador. Fica patente mais uma vez, e através da representação do outro, que na mentalidade da época assentou toda a interpretação da realidade - não se descobriu algo novo, mas sim, encontrou-se algo que estava previamente configurado no imaginário colectivo ${ }^{15}$.

Velho e Novo continentes foram representados graficamente mediante alegorias, traduzindo simbolicamente a imagem, os atributos, as qualidades

${ }^{13}$ De Optimo Reipublicae Statu deque Nova Insula Utopia (português: Sobre o melhor estado de uma república e sobre a nova ilha Utopia) ou simplesmente Utopia é o livro de escrito em 1516 por Thomas More (1480-1535), em latim, tornando-se sinónimo de um projecto irrealizável: fantasia; delírio; quimera; lugar que não existe, amplificando o termo "utopia".

${ }^{14}$ TODOROV, Tzevetan - A conquista da América ..., cit., p. 64.

15 TODOROV, Tzevetan - A conquista da América ..., cit. 
e as especificidades de cada espaço físico. A figura feminina serviu de alegoria dos dois "mundos". A figura da América foi personificada por uma índia e ganhou forma pelos traços do maravilhoso, do exótico, da riqueza dos detalhes. Uma índia nua e bárbara, adornada com penas tal como as descrições dos primeiros conquistadores, simboliza nos sécs. XVI e XVII, a inferioridade do Novo Mundo e a sua subordinação à Europa ${ }^{16}$ :

“[...] a Europa [...] era como uma mulher, 'com veste de soberana, com coroa, cetro e segurando o globo imperial'. A superioridade está indicada pela imagem de uma rainha que possuía em suas mãos o domínio sobre o globo... A América se fez conhecer como uma mulher nua, segurando uma cabeça de homem cortada. Marcando o estado de barbárie em que viviam suas populações..." ${ }^{17}$

Através da iconografia foi frequente a representação de caravelas, mais como elo de ligação à origem do que à própria América. Água e caravelas (que desafiavam as proporções das terras cartografadas) funcionavam como o elo gráfico e simbólico entre Europa e América.

Desde os inícios do séc. XVI que ocorre uma guerra de imagens ${ }^{18}$ no espaço colonial ${ }^{19}$, como tentativa de impor uma nova ordem visual e monopolizar a representação do sagrado, enquanto dispositivo de denominação simbólica e real, tentando a domesticação dos sentidos. Desde então até aos nossos dias, que coexistem símbolos do catolicismo com símbolos profanos, vindo a ser incorporados e recreados na sua representação e interpretação.

Todas as narrativas e crónicas das descobertas configuraram-se na apologia do poder do homem europeu sobre o indígena e sobre o novo mundo natural. Pelas narrativas de viagem foram veiculadas as ideias pessoais dos autores que pretendiam fazer descrições detalhadas e minuciosas da geografia, da natureza e do indígena relacionando-os com os mitos e as crenças medievais. Deste modo, estes documentos permitem-nos

${ }^{16}$ Séculos mais tarde, durante os movimentos de independência, os americanos utilizaram a imagem da índia, convertendo-a num símbolo da liberdade, da resistência à opressão desde a conquista.

${ }^{17}$ THEODORO, Janice - Descobrimentos e Renascimento. São Paulo: Contexto, 1991, p. 16-17.

${ }^{18}$ GRUZINSKI, Serge - A Guerra das Imagens: de Cristóvão Colombo a Blade Runner (1492-2019). São Paulo: Companhia das Letras, 2006.

${ }^{19}$ Gruzinski delimita o seu estudo ao México colonial (Nova Espanha). 
aceder à dimensão antropológica das descobertas, sobre a perspectiva eurocêntrica, permitindo a abordagem, a compreensão e o entendimento das transformações de mentalidades dos navegadores deste período fulcral construção e edificação da modernidade.

Desde a Antiguidade que as viagens se constituem como elo estruturador de relatos e descrições, onde os seus autores dão conta de elementos do maravilhoso. Estas descrições converteram-se numa constante das narrativas de viagem durante toda a Idade Média, prolongando-se até inícios do séc. XVII, o mesmo se constata nos documentos que relatam a descoberta do Novo Mundo. Esclarece O'Gorman, num estudo introdutório à obra do padre José de $\mathrm{Acosta}^{20}$, Historia natural y moral de las Indias (1590), que a:

“... geografía y antropología maravillosas presentes en el mundo greco-helenístico y romano como producto de los relatos de viajeros y de las recopilaciones de enciclopedistas, porque buena parte de sus contenidos, confluyen hacia el relato de los viajes de Alejandro y hacia la descripción de los paisajes y países, auténticos y fabulosos, que en ellos aparecen; y porque también de ella deriva en gran medida el imaginario de los siglos medievales, presente en sus viajeros, reales o míticos y en sus recopiladores y enciclopedistas" ${ }^{\prime 21}$.

No destino, o esperado foi o fantástico, o monstruoso. Seres fantásticos e extraordinários, animais míticos, costumes estranhos já patentes nas descrições de Plínio ${ }^{22}$ e de Marco Polo, converteram-se numa obsessão para os navegadores: sereias, amazonas, canibalismo, sodomia, monstros marinhos, unicórnios. Seres que vêm desde a Antiguidade e ficaram perfeitamente estampados no imaginário colectivo dos descobrimentos.

Todos estes seres míticos e fantásticos, que foram motivo de medos e receios entre os viajantes, foram entendidos não como pertencentes a um espaço infernal, não como a negação do Paraíso Terrestre, mas como seres

${ }^{20}$ José de Acosta (1539-1600), padre jesuíta, cosmógrafo e historiador espanhol. O livro Historia natural y moral de las Indias (1590), pretende dar resposta aos grandes mistérios da sua época. Acosta foi um dos pilares fundamentais do pensamento cientifico do séc. XVI.

${ }^{21}$ O'GORMAN, Edmundo (ed.) - Prólogo in ACOSTA, José de - Historia natural y moral de las Indias. México: Fondo de Cultura Económica, 1940. Tomo I, p. 24-25.

${ }^{22}$ Plínio (23d.C.-79), romano, importante naturalista da antiguidade, foi modelo para os cronistas da primeira metade do séc. XVI, sendo citado mais de cem vezes, na Historia general y natural de las Indias de Fernandéz de Oviedo. 
concebidos pela vontade divina e que integram o jardim do Éden: "Senhor Deus, como tuas diversas obras são maravilhosas em todo o universo!" (Salmo 104).

Durante a Idade Média, a natureza impôs-se à sociedade, marcando os ritmos quotidianos: a natureza, sendo temida era sacralizada e respeitada dentro de um pensamento fundamentalmente mágico, mesmo quando a igreja aludia às forças da natureza como manifestações da potência criadora de Deus. Santo Agostinho concebeu o mundo como um livro de origem divina que, para se compreender, necessitava de ser lido e descodificado à luz do seu Criador, só desse modo se compreenderiam os desígnios divinos ${ }^{23}$.

\section{Bestiários do Novo Mundo: a bestialização do Outro}

A Espanha procurou no Novo Mundo a "confirmação" da existência do maravilhoso medieval. Sereias, amazonas, gigantes, unicórnios, canibais, pessoas sem cabeça ou com cauda e pessoas com enormes orelhas, são exemplos desse maravilhoso, dispersos em múltiplos relatos e crónicas, sendo mobilizados e reconfigurados no séc. XVI, como bestiários do Novo Mundo. Estas imagens, mais que representar o outro, dão conta da adaptação de um imaginário colectivo, europeu, que é mobilizado para a apreensão e concepção de uma novo mundo, adaptando-se à realidade encontrada. A imagem do outro começa a ser uma imagem estereotipada ${ }^{24}$, através da monstruosidade.

A própria Bíblia investe-se como importante fonte de explicação da existência dos novos animais, das novas terras e a sua origem. O Génesis alude à Arca de Noé que salva todos os animais e os difunde pelo mundo, "pues conforme a la Divina Escritura, todos estos animales se salvaron en el Arca de Noé, y de alli se han propagado en el mundo ${ }^{25}$.

${ }^{23}$ CHAMBEL, Pedro Alexandre Sacadura - Os Animais na Literatura Clerical Portuguesa dos Séculos XIII e XIV: Presença e Funções. Tese de Doutoramento (texto Policopiado). FCSH/UNL, 2003.

${ }^{24}$ MASON, Peter - Deconstructing America: representations of the other. London: Routledge, 1990.

${ }^{25}$ ACOSTA, José - Historia Natural y Moral de Las Indias. Biblioteca Virtual Miguel de Cervantes Saavedra. Alicante: Universidad de Alicante, 1999 [1590], p. 230. 
Os novos seres encontrados foram alvo de admiração e conotados com o monstruoso (por exemplo o tucano, por ter um bico maior que todo o seu corpo). Se foram alvo de espanto, foram ao mesmo tempo alvo de medos e receios, vendo-se neles a grandeza de Deus na sua criação, mas também o poder do Demónio. Foi ambivalente a interpretação do novo mundo natural: maravilhas de Deus ou obra do Diabo.

Os animais do Novo Mundo (imaginários ou reais) foram muitas vezes codificados moralmente à maneira dos Bestiários medievais de frades e cronistas $^{26}$. À luz das características e dos comportamentos dos seres naturais, que Deus neles tinha inscrito, procurou-se compreender os ensinamentos morais a serem observados pelos cristãos ${ }^{27}$.

Gonzalo Fernández de Oviedo ${ }^{28}$ deu-nos conta de um autêntico bestiário do Novo Mundo nas páginas das suas obras, apoiando-se grandemente nas leituras de Plínio e Aristóteles. Tentou descrever os animais por semelhança e comparação com os da Europa ou com as descrições de seres do imaginário medieval, contudo, quando não encontrava referências claras para os animais exóticos que observava, descrevia-os como os seres híbridos dos bestiários da antiguidade, como é o caso da iguana, do tatu, do tlacuache ${ }^{29}$.

O outro desconhecido também foi concebido como besta, tendo sido comum a sua representação como uma besta, como um monstro, estabelecendo-se sempre a conexão a figuras míticas como o "bom selvagem" cujo habitat é semelhante às imagens do paraíso. Todo o imaginário e fantasia, produtores de imagens, implicam uma noção de fronteira, emergindo desse modo o Novo Mundo como um espaço que está para lá das "fronteiras" do mundo europeu ${ }^{30}$. São diversas as representações acerca do outro monstruoso aos olhos dos europeus. As crónicas da conquista, as narrativas de viagem e toda a iconografia sobre o outro do Novo Mundo.

${ }^{26}$ RODILlA LEÓN, Maria José - Bestiários del Nuevo Mundo: Maravillas de Dios o Engendros del Demónio. Rev. Destiempos. 3 (14) (2008) 25-34.

${ }^{27}$ CHAMBEL, Pedro Alexandre Sacadura - Os Animais na Literatura Clerical ..., cit.

${ }^{28}$ Cronista e naturalista das Indias que escreveu em 1522 o Bestiario de Indias, para informar Carlos V, rei de Espanha, dos animais dos seus novos domínios.

${ }^{29}$ FERNÁNDEZ OVIEDO, Gonzalo - Historia general y natural de las Indias. Biblioteca Virtual Miguel de Cervantes Saavedra. Alicante: Universidad de Alicante, 1851 [1535].

${ }^{30}$ SCHOENNENBECK, Sebastián - América monstruosa y la novela monstruosa de José Donoso. Revista Laboratorio, 1 (2009). 
Uma gravura em madeira (datada de 1505), que pretende ilustrar a terceira viagem de Américo Vespucio, revela-nos como os índios foram apreendidos, mediados pelo imaginário do europeu. Com efeito, os indígenas têm a pela avermelhada, comem carne humana e vivem "sem" regras. A gravura acompanhada de texto descritivo (aquilo que hoje se pode assumir como uma fábula), ilustra bem as representações que o europeu construiu sobre o outro:

"Tanto los hombres como las mujeres andan desnudos, poseen un cuerpo bien proporcionado y tienen una piel casi de color rojo. Tienen perforadas las mejillas y los labios, la nariz y las orejas y adornan estas incisiones con piedras azules, pedazos de vidrio, mármol y alabastro muy finos y hermosos. Esta costumbre es propia, sin embargo, sólo de los hombres. No existe entre ellos ningún tipo de propiedad privada, sino que todas las cosas pertenecen a la comunidad. Viven todos juntos, sin rey o jefe de ninguna especie y cada uno es su propio señor. Toman como esposa la primera que encuentran y actúan en todo sin atenerse a ley alguna. Luchan entre ellos sin arte ni regla, se devoran unos a otros, incluyendo muertos, pues la carne humana es una de las formas habituales de alimentación. Acostumbran a salar carne humana y a colgarla de las casas con el objeto de que se seque. Alcanzan la edad de ciento cincuenta años y rara vez se enferman" ${ }^{31}$.

Os europeus que aportaram no Novo Mundo levaram consigo um horizonte de expectativas que foram prefiguradas nos textos dos viajantes da antiguidade, correspondendo a percepção dos novos territórios e do outro e a forma como estes se textualizam ao universo das expectativas (cristãs e pagãs) partilhadas pelos navegadores ${ }^{32}$. Muitos dos traços atribuídos pelo europeu ao indígena já estavam no seu imaginário ${ }^{33}$.

As imagens do indígena, mais que representar o "homem" do quarto continente, pretenderam traduzir os mitos, as histórias de maior difusão na Europa. Perante o encontro do Novo Mundo, tinham duas opções: reconhecer

${ }^{31}$ Cit. por ROXAS MIX, Manuel - América Imaginada. Madrid, Lumen. 1992, p. 5-6.

${ }^{32}$ LÓPEZ MARISCAL, Blanca. - Modelos narrativos para los cronistas del Nuevo Mundo: una mirada a los textos fundantes in PASCUAL BUXÓ, José; RODRÍGUEZ HERNÁNDEZ, Dalia; RODRÍGUEZ HERNÁNDEZ, Dalmacio (eds.) - Permanencia y destino de la literatura novohispana: Historia y Crítica. México, UNAM: Instituto de Investigaciones Bibliográficas, 2006, p. 57-68.

${ }^{33}$ Por exemplo, o ressurgir do mito das amazonas (mulheres guerreiras cujas comunidades excluem os homens) no Novo Mundo. 
a inutilidade do seu saber e proceder à descoberta das novas terras ou manter a sua concepção do mundo e tratar de se adaptar à realidade encontrada.

Conceber o outro como monstro foi um processo que permitiu constatar um particular mecanismo de construção da alteridade, numa espécie de lógica de círculos concêntricos, em que no centro estaria a civilização, a qual estaria rodeada de inúmeros povos bárbaros, que são identificados como monstruosos. Assim, sempre que o conhecimento se estendeu além do limite do conhecido, emergiram seres monstruosos que se opunham conhecimento do europeu e à sua cultura ${ }^{34}$.

As ilustrações de Theodore De Bry ${ }^{35}$ são tradutoras de um imaginário concreto sobre o Novo Mundo. Junto dos discursos sobre o Novo Mundo, as imagens gráficas actuaram "politicamente", difundindo uma realidade de determinada ordem de indígenas. À margem da verdade e da verosimilhança, as imagens produzidas e tradutoras do outro pretenderam instituir um discurso específico sobre ele e sobre o Novo Mundo ${ }^{36}$. Mas impõem-se algumas questões: porquê a figura do Monstro? Que significado tem o monstruoso na cultura europeia do séc. XVI? Que torna o habitante do Novo Mundo um monstro? Como se manifesta a monstruosidade do outro?

A imagem do monstro pode ser associada à noção de pecado. $\mathrm{O}$ pecado do outro configurou-se como o estranho, o exótico, o pagão. O outro encontrava-se condenado à bestialização por ser pecador e, como tal, deveria ser punido e eliminado ${ }^{37}$. A representação imaginária e gráfica do outro como monstro emergiu como elemento simbólico em que e bestialização e a monstrificação foi o resultado do pecado:

"Enumerar lo monstruoso no nos interesa por lo pintoresco, sino por lo emblemático, porque son expresión del pecado de ser lo otro. Si el nombre se aplica al ente cuyas costumbres o cuya morfología se

${ }^{34}$ CARREÑO, Gastón - El Pecado de Ser Otro. Análisis a Algunas Representaciones Monstruosas del Indígena Americano (Siglos XVI-XVIII). Revista Chilena de Antropologia Visual. 2008.

35 Theodore De Bry (1528-1598), gravador holandês que, apesar de nunca ter estado no Novo Mundo, produziu inúmeras ilustrações sobre as Américas.

${ }^{36}$ EGAÑA, Daniel - Lo monstruoso y el cuerpo fragmentado: el Nuevo Mundo como espacio de violencia, una lectura de la obra de Theodore De Bry en la construcción de la imagen indiana. Revista Chilena de Antropologia Visual. 16 (2010) 1-29.

${ }^{37}$ Idem. 
aparta de nuestras normas estéticas o éticas, aplicado al hombre, toma el sentido de lo extraño, extranjero... Los monstruos forman parte de una información general de lo extraño, proporcionada por escritores y cartógrafos. Introducen el exotismo y simbolizan el paganismo. A menudo en miniaturas que ilustran escenas de batallas, entre las huestes enemigas desfilan endriagos y hombres salvajes. Darles muertes es un deber: era servir a Dios y al derecho" 38 .

A descrição do outro pretendia traduzir a sua identidade: comunidades acéfalas, comunidades de seres com grandes orelhas ou com cauda, de gigantes ou com práticas canibais são alguns dos exemplos de como o outro é visto no Novo Mundo.

Uma das primeiras representações que assumiu o indígena foi a de Acéfalo, cuja imagem tinha antecedentes na cultura helénica. Seres acéfalos foram encontrados por aventureiros no Egipto, Líbia, Índia e China. O corsário inglês Walter Raleig descreveu os acéfalos do modo seguinte "cerca de ella viven los poderosos Ewaipanomas [acéfalos], hombres sin cabeza, con sus ojos y boca en el pecho, muy similares a los acéfalos orientales, pero tienen pelos en la espalda. Son capaces de manipular arcos tres veces más grandes que los normales "39. O corpo seria o reflexo da alma, sendo, portanto, considerado obra diabólica. O acéfalo, não tendo cabeça, encarna o mal. Inúmeros cartógrafos identificaram diversas zonas do Novo Mundo como locais onde seria possível encontrar acéfalos.

Outra imagem que traduziu o indígena do Novo Mundo foi a de gente com Grandes Orelhas que cobriam todo o corpo, utilizando uma orelha para se deitar sobre ela e a outra para se tapar ${ }^{40}$. O mito dos homens de Grandes Orelhas era uma tradição que remontava aos textos clássicos e estava representado em pinturas e esculturas de diversas igrejas na Europa. Deste modo deu-se conta da realidade do Novo Mundo, reproduzindo e validando a mitologia do Velho Mundo.

Uma outra representação ilustrou o indígena como Gente com Cauda. Foi Colombo quem primeiro deu conta desta "particularidade" ao descrever

\footnotetext{
${ }^{38}$ ROXAS MIX, Manuel - América Imaginada..., cit., p. 66-67.

${ }^{39}$ MAGASICH-AIROLA Y DE BEER cit. por CARREÑO in CARREÑO, Gastón El Pecado de Ser Otro. Análisis a Algunas Representaciones..., cit., p. 130.

${ }^{40}$ ROXAS MIX, Manuel - América Imaginada..., cit.
} 
os indígenas da ilha de Santa Joana, "por la parte que mira a occidente, restan aun dos provincias que no reconocí, y de las cuales á la una llaman los indios Anam, y cuyos habitantes nacen con cola"41, instaurando uma tradição de monstrificação do outro, que viria a legitimar a usurpação e domínio dos novos territórios.

Uma das lendas de maior difusão na literatura e arte europeia medieval foi a lenda do Gigante. Américo Vespúcio foi o primeiro a relatar a existência de gigantes no Novo Mundo, tendo-os "encontrado" no Curaçao,

"encontramos una población de unas doce casas, donde hallamos sino siete mujeres, de tan grande estatura, que no había ninguna que no fuera un palmo y medio más alta que yo.... Y mientras que estábamos en esto vinieron 36 hombres y entraron en la casa donde estábamos bebiendo, y eran de tal estatura que cada uno de ellos era más alto arrodillado que yo en pie"42.

Inúmeras cartas geográficas designaram por "regio gigantum" "43 a região da Patagónia, local de consenso onde se encontravam esses gigantes. António Pigafetta, cronista da viagem de Fernão de Magalhães, escreveu acerca do seu encontro com os habitantes de altura anormal da "regio gigantum":

"Un día, cuando menos lo esperábamos, un hombre de figura gigantesca se presentó ante nosotros. Estaba sobre la arena casi desnudo, y cantaba y danzaba al mismo tiempo, echándose polvo sobre la cabeza. El capitán [Fernão de Magalhães] envió a tierra a uno de nuestros marineros, con orden de hacer los mismos gestos, en señal de paz y amistad, lo que fué muy bien comprendido por el gigante, quien se dejó conducir a una isleta donde el capitán había bajado. Yo me encontraba allí con otros muchos. Dio muestras de gran extrañeza al vernos, y levantando el dedo, quería sin duda decir que nos creía descendidos del cielo. - Su figura: Este hombre era tan grande que nuestra cabeza llegaba apenas a su cintura..."

${ }^{41}$ FERNANDEZ cit. por CARREÑO in CARREÑO, Gastón - El Pecado de Ser Otro. Análisis a Algunas Representaciones..., cit., p. 132.

${ }^{42}$ ROJAS MIX cit. por CARREÑO in CARREÑO, Gastón - El Pecado de Ser Otro. Análisis a Algunas Representaciones..., cit., p. 133.

${ }^{43}$ Idem

${ }^{44}$ PIGAFETTA, Antonio - Primer Viaje en torno del Globo [1536]. Edición del IV Centenario. Madrid: Calpe, 1922, p. 52. 
O gigante representava a barbárie, a desproporção e a força destrutiva - características tradutoras da forma como a Europa vê o Novo Mundo e se justifica a si mesma ${ }^{45}$.

Em determinado momento, por todos os dados empíricos que se foram perfilando, o outro imaginado foi confrontado com o outro encontrado. Contudo, a imagem mítica do indígena resistiu à sua adequação com a realidade, até que as características do outro a conseguem dissipar até à emergência da produção de uma nova imagem mítica que resgata alguns traços anteriores e produz imagens mais flexíveis na sua confrontação com o real. Ocorreu uma reciclagem da monstruosidade do indígena, passando a constituir-se como um ser aberrante, não pelo seu aspecto físico mas pelos seus costumes. Pela impossibilidade de revelar a monstruosidade física do outro, recorreu-se a monstrificação das suas práticas culturais ${ }^{46}$.

A antropofagia acentua o carácter monstruoso do outro, constituindo-se este como um elemento importante que o afasta radicalmente da natureza do europeu. Cronistas e viajantes descreveram os hábitos canibais de grande parte dos indígenas do Novo Mundo e é Vespucio quem comparou as práticas de cozinha europeias com as práticas canibais.

Hans Standen através da sua obra, "Véritable histoire et description d'un pays habité par des hommes sauvages, nus, féroces et anthropophages" (1557), difundiu com detalhe as práticas canibais dos indígenas do Novo Mundo, sendo esta obra, mais tarde, recreada visualmente por Theodor De Bry. Uma ilustração cartográfica do séc. XVI, atribuída a Hans Holbein, o Jovem, ilustra na sua parte inferior cenas canibais, indicando o mapa mundi de então a existência de tais práticas naquele espaço do mundo ${ }^{47}$.

A representação do outro como monstro resultou de uma complexa produção cultural em que foi concretizado um recorte da realidade, ocorrendo não só a projecção das intenções conscientes do autor, mas também as projecções de um todo cultural social ao qual se pertence. Toda a interpretação da iconografia sobre o outro dependeu grandemente da interpretação da sua

\footnotetext{
${ }^{45}$ Idem, ibidem, p. 82.

${ }^{46}$ CARREÑO, Gastón - El Pecado de Ser Otro. Análisis a Algunas Representaciones..., cit.

${ }^{47}$ SCHOENNENBECK, Sebastián - América monstruosa y la novela monstruosa..., cit.
} 
cultura e história. Cada imagem é um fragmento de um todo da produção visual, orientada para a descrição e tradução duma realidade desconhecida, a partir de um universo conceptual conhecido.

O encontro entre duas culturas gera uma produção de imagens estereotipadas. Estas imagens podem não ser completamente falsas, mas que exageram determinados elementos da realidade ou omite outros. A criação de um estereotipo pode ser mais ou menos cruel, mais ou menos violento, contudo, em qualquer dos casos, carece necessariamente de nuances ${ }^{48}$.

Todas as representações sobre a monstruosidade do outro culminaram na (re)construção de um imaginário particular sobre o Novo Mundo, conferindo sentido, quer ao indígena, quer às categorias conceptuais europeias. O imaginário assumiu-se como o aspecto central na construção de opiniões, crenças e concepções sobre os novos territórios.

\section{Os outros filhos de Adão e Eva: origem e natureza do outro}

O europeu ao chamar índio ao nativo conferiu-lhe uma nova identidade. Ainda hoje nos referimos a ele com essa designação ou, à semelhança dos conquistadores espanhóis do séc. XVI, continuamos a considerá-lo como o Outro. Este aspecto explica-se pelo facto de que:

“... desde el momento mismo en que los europeos pusieron los ojos sobre los aborígenes de este continente, éstos dejaron de tener una historia propia para pasar a ser personajes secundarios de la historia ajena. La invasión europea no sólo destruyó su religión y costumbres, sino que les arrebató su identidad. De ser individuos dentro de un grupo humano específico, pasaron a ser clasificados bajo un único membrete, el de «indios» que ni siquiera se refiere a ellos estrictamente hablando. El europeo, proviniera de donde proviniera, nunca vio en estos hombres lo que, para bien o para mal, eran, sino lo que él consideraba que eran o que debían ser [...]. Puede decirse que ninguno de los grandes

48 BURKE, Peter - Eyewitnessing. The uses of Images as Historical Evidence. New York: Cornell University Press, 2008. 
defensores del indio - franciscanos, dominicos, agustinos o jesuitas, lo mismo da - logró comprender la naturaleza de estos hombres" ${ }^{\prime 4}$.

Importa debater a questão da origem e natureza do outro aquando da sua "descoberta".

Aquando da descoberta do "Quarto Continente", a temática relativa à origem dos seus habitantes nativos (os índios) emergiu como debate intenso entre os eruditos da época. A sua alusão nos textos da época foi resultante da capacidade de assumir uma nova e desconcertante realidade, da qual não se tinha qualquer conhecimento. O Novo Mundo suscitou um acalorado e profundo interesse, na medida em que era revelado aos olhos da velha Europa um mundo completamente novo, evidenciando a "inutilidade" das prédicas evangélicas e dos textos sagrados, que preconizavam que a palavra de Deus tinha alcançado todos os confins da terra ${ }^{50}$.

Os primeiros anos da conquista monopolizaram a atenção dos cronistas na descrição dos novos territórios e dos povos indígenas evitando, de certo modo, focar a problemática da origem dos índios (o que implicava dificuldades teológicas e de interpretação das Sagradas Escrituras). Só na segunda metade do séc. XVI surgem diversas hipóteses, assentes em fontes históricas (sagradas e profanas), tentando explicar o que ocorreu com as tribos perdidas de Israel, onde foram parar os habitantes da desaparecida Atlântida, onde ficava localizado o Paraíso Terrestre, se teriam ou não chegado Apóstolos ao Novo Mundo ou, até mesmo, onde tinham chegado os filhos de Noé na sua missão de povoar o mundo após o dilúvio ${ }^{51}$.

Após as iniciais e múltiplas conjecturas teológicas que consideravam o indígena como criatura sem alma (e como tal, não pertencente à espécie humana) estando apto para ser escravizado, apareceram opiniões de novos autores, relativamente à origem do "índios do ocidente”. Ambas as correntes

${ }^{49}$ FROST cit. por ESPINOSA in ESPINOSA, Maria del Carmen - La Palabra Conquistadora. Las Crónicas Jesuitas sobre el Noroeste Novohispano. Anales de Literatura Española. 13 (1999) 167.

${ }^{50}$ FERNÁNDEZ MARCOS, Natauo; FERNANDEZ TEJERO, Emilia - Biblia $y$ Humanismo. Textos, talantes y controversias del siglo XVI español. Madrid: Fundación Universitária Española, 1997.

${ }^{51}$ CAMACHO DELGADO, José Manuel - Los nuevos hijos de Adán. Diego Andrés Rocha y el origen de los Indios Occidentales in BARRERA, T. (ed.) - Herencia Cultural de España: siglos XVII y XVIII. Madrid: Iberoamericana, 2008, p. 149-170. 
convergiram em dois pontos essenciais: a) todos os homens, do Novo e Velho mundos, descendem dos primeiros pais bíblicos - Adão e Eva; b) os primeiros habitantes aportaram ao Novo Mundo após o Diluvio Universal (assegurando a descendência directa de algum dos três filhos de Noé: Sem, Cam ou de Jafet).

Autores contemporâneos, caso de Miguel Valboa ${ }^{52}$, tentaram explicar a origem dos índios ocidentais, mobilizando os argumentos "credíveis" disponíveis. Era imprescindível demonstrar (com base nalguns versículos Bíblicos - Livro I dos Reis, cap. 9, versículos: 10 e 11 e 26 a 28 - nos quais se faz alusão às viagens realizadas pelos judeus a uma terra incógnita e misteriosa chamada de $\mathrm{Ofir}^{53}$ ) que os habitantes do Novo Mundo descendiam de Adão e Eva pois, caso contrário, seria difícil sustentar o argumento de serem verdadeiros homens com alma (o argumento de que o indígena não tinha alma era sustentado por aqueles que o pretendiam escravizar). Assim, identifica-se a América com o mito de Ofir.

Mas, de onde procediam aqueles povos? O padre Acosta considerava que os descobrimentos realizados revelaram a existência de povos que antigos autores (Plínio, Séneca) já tinham preconizado ${ }^{54}$. Até mesmo a própria Bíblia "insinua" a existência do Novo Mundo. Para Acosta esses habitantes eram descendentes de Noé e, portanto, descendentes remotos de Adão e Eva. Acosta levanta duas hipóteses polémicas para a época: a origem judaica do novo povo encontrado ou a sua possível proveniência da Atlântida (segundo Platão, a Atlântida era um espaço tão grande como a África e a Ásia juntas). Os estudiosos (exegetas) da época chegaram mesmo a analisar as semelhanças entre judeus e índios. Relativamente aos povos que habitavam o novo continente, Frei Juan de Torquemada ${ }^{55}$ lamentou a falta de documentos, tendo claro que eram um povo muito antigo:

${ }^{52}$ Miguel Cabello Valboa (1535-1608), clérigo e cronista espanhol, autor de Miscelánea Antártica (1586), obra fundamental da historiografia americana.

${ }^{53}$ Região mencionada na Bíblia, onde há abundância de ouro e outras riquezas. Colombo, após a sua terceira viagem, identifica o Haiti com o Ofir bíblico, assente nas considerações de inúmeros pensadores da época.

${ }^{54}$ ACOSTA, J. - Historia Natural y Moral..., cit.

${ }^{55}$ Fr. Juan de Torquemada (1557?-1624), padre franciscano e historiador. Autor de obras relacionadas com o México do séc. XVI. 
"Fuerza es que no habiendo noticia de los antiguos morado res y naturales de esta tierra. de qué gente sea. ni de qué familia haya venido. ni en nuestra España haya tal noticia de ninguno de los escritores, que andemos a ojos cerrados dando vueltas y rodeando la verdad y por ventura no llamando a su puerta en mucho tiempo; y así me parece que debieron de ser de alguna gente antiquísima de aquella que se repartió y dividió luego después del Diluvio..." 56

E como se difundiram os habitantes da terra? Como chegaram até este Novo Mundo? O Frade Gregório Garcia ${ }^{57}$ tentou conciliar todas as teorias da época sobre a questão, sintetizando de forma ecléctica e enciclopédica a origem do índio do ocidente s. $^{58}$

1) os primeiros habitantes chegaram por mar, com orientação da altura do Pólo, pela posição das estrelas e por algum instrumento de navegação. Supõe-se que tivessem algum conhecimento daquelas terras;

2) Acosta considerou que chegaram por vontade própria, ou mesmo, arrastados por marés ou por tempestades;

3) os primeiros indígenas chegaram caminhando, sem rumo, ao longo dos tempos;

4) Alejo Venejas considerava a possível origem cartaginesa;

5) originários das dez tribos de judeus, cativas do rei da Assíria, Salmanasar;

6) Garcia cita Arias Montano apontou que os habitantes da Nova Espanha e do Perú eram originários do mítico território de Ofir;

7) seguindo Gómara e Agustín de Zárate, recriou a lenda da Atlântida, cujas dimensões colossais permitiram a chegada dos europeus às ilhas de Barlovento e daí povoar terra firme;

8) outra hipótese, que deriva da anterior, foi a possibilidade de tais viagens às Índias terem ocorrido na época pós-romana, quando parte da península falava a língua castelhana;

${ }^{56}$ TORQUEMADA, Juan - Monarquía indiana de los veinte y un libros rituales $y$ monarquía indiana, con el origen y guerras de los indios occidentales, de sus poblazones, descubrimiento, conquista, conversión y otras cosas maravillosas de la mesma tierra. México: Universidad Nacional Autónoma de México, Instituto de Investigaciones. 1979 [1615], vol. 1, cap. IX, p. 36.

${ }_{57}$ Autor da obra Origen de los indios del Nuevo Mundo y Indias Occidentales (1607).

${ }^{58}$ CAMACHO DELGADO, José Manuel - Los nuevos hijos de Adán..., cit. 
9) que os habitantes tinham origem nos gregos;

10) ou que tenham origem nos fenícios.

A temática da origem do índios detinha em pleno séc. XVII, não apenas um valor antropológico mas também importantes implicações no âmbito do direito, da política e da economia. Defender qualquer das posturas era legitimar a pertença dos territórios do ultramar, como forma de recuperar espaços que outrora pertenceram à coroa espanhola ${ }^{59}$.

O cronista Diego Andrés Rocha, na sua obra Tratado Unico Y Singular Del Origen De Los Indios Del Peru, Mejico, Santa Fe Y Chile (1681), construiu um discurso mobilizando e manipulando textos bíblicos, tendo por fim interesses políticos e estratégicos da coroa espanhola. O cronista considerou, então, que o povoamento do Novo Mundo ocorreu após o dilúvio, onde teve papel importante Jafet, filho de Noé, e cujos descendentes passaram às Índias ocidentais, graças à proximidade da Atlântida:

"Que estas Indias occidentales, después del diluvio universal, se comenzaron a poblar por los descendientes de Jafet, hijo de Noé; hijo de Noé; de Jafet descendió Tubal, quien pobló a España, (...) y sus descendientes la ocuparon y poblaron, y de ellos, como estaban vecinos a la isla Atlántida, vinieron poblando por ella y llegaron a tierra firme, que corre por la parte de Cartagena, y va bojeando todo este mar del Sur por sus costa hasta el cabo Mendozino y estrecho y reino de Anian y provincia Quivira, confinante con el Asia, que todo este círculo de tierra, contando por el Norte y Sur, hacen más de 700 leguas, mediando también el estrecho de Magallanes. Que éstos fuesen los primeros, lo dicta la razón, y también la cercanía del continente de Cádiz con Cartagena de estas Indias, pues de aquél a ésta se continuaba la isla Atlántida por mil leguas y más, como con evidencia se probó..." ${ }^{90}$.

Assistimos, portanto, ao uso político do indígena, mobilizando inclusive argumentos teológicos, para justificar a legitimidade das possessões de Espanha no Novo Mundo. Como reforço da argumentação teológica, Andrés Rocha apresenta a América como uma recompensa de Deus aos Reis Católicos, por terem expulso os mouros e judeus da Península.

${ }^{59}$ CAMACHO DELGADO, José Manuel - Los nuevos hijos de Adán..., cit.

${ }^{60}$ ANDRÉS ROCHA, Diego - Tratado Unico Y Singular Del Origen De Los Indios Del Peru, Mejico, Santa Fe Y Chile. Madrid: Ediciones elaleph.com, 2000 [1681], p. 46. 
Rocha chegou a comparar Fernando, o Católico, a Moisés, estabelecendo um paralelismo entre a conquista da Terra Prometida por Israel (libertando-a da opressão do Egipto) e a Conquista do Novo Mundo por Espanha (salvando os indígenas do pecado mortal e trazendo-os para o fé católica). E a origem dos animais que se encontram no Novo Mundo? Muitos destes não tinham correspondente no mundo conhecido. Escreve Frei Juan de Torquemada que estes obviamente eram provenientes da Arca de Noé:

“... que como los ángeles los trajeron al Arca para que en ella se salvasen y no pereciesen de todo punto, de esa misma manera los pasarían a diversas partidas del mundo, para que allí se conservasen y aumentasen; y no disuena esta razón a buen entendimiento, antes es conforme a ella; pues no es tan sabrosa la compañía de una bestia fiera que obligue a un hombre a que la desee, antes huye de ella como del enemigo." ${ }^{\prime 61}$

Numa postura racionalista, o padre Acosta aponta de "qué manera pasaron bestias y ganados a las tierras de Indias" ${ }^{2}$, esclarecendo que os animais entraram no Novo mundo devido à proximidade dos continentes.

Todo o debate sobre a construção social e cultural do outro (da sua origem e da sua natureza) é um debate que assume a centralidade entre os eruditos dos séculos XVI e XVII, ao constatarem a existência de um novo mundo e, fundamentalmente, de um Novo Homem. Toda a discussão e compreensão antropológica do Outro desta época permite, em muito, aceder à compreensão antropológica do Homem de Hoje da América Latina, no que diz respeito à construção da sua identidade e modo de ser e estar no Mundo.

\section{Comentário Final}

A empresa dos descobrimentos do Novo Mundo foi herdeira do espirito medieval. A "quarta parte do mundo", inicialmente inventada, fruto de todo um repertório do imaginário construído e acumulado foi sendo descoberta.

${ }^{61}$ TORQUEMADA, Juan - Monarquía indiana de los veinte y un libros rituales..., cit., Livro I, cap. VIII, p. 36.

${ }^{62}$ ACOSTA, J. - Historia Natural y Moral..., cit., cap. XXI, p. 60. 
O imaginário medieval cedeu lugar à construção do conhecimento da modernidade, pelas explorações cientificas que permitiram conhecer, classificar, ordenar e organizar o conhecimento e o mundo.

A Europa deslocou toda a esfera do imaginário mítico e teológico medievais para os novos territórios e, ao mesmo tempo, encontrou novos "elementos" que permitiram aos produtores de imagens reconstruir velhos mitos. A América a partir da sua descoberta transformou-se num verdadeiro "viveiro" e repositório de imagens intimamente ligadas ao imaginário Europeu, herdeiro de uma tradição cristã. Não podemos compreender a América se esquecemos que ela é fruto das Utopias Europeias. São os mitos trazidos do Velho Continente que nos permitem compreender o nascimento da Utopia renascentista.

Do contacto com um novo mundo, com uma nova realidade, decorre o nascimento da modernidade com a evolução do conhecimento (sobre a cartografia, a fauna, a flora) e uma discussão antropológica e filosófica sobre o outro. Olhar o outro, segundo a discussão e concepção erudita da época, vai muito além da análise antropológica e etnográfica, tocando as preocupações religiosas e políticas.

O imaginário permitiu aos europeus desvendar o novo, o maravilhoso e o extraordinário. Os mitos da antiguidade quase que assumiram uma identidade e uma confirmação da sua real existência no contacto com o novo mundo natural e com os novos filhos de Adão e Eva. Atribuir ao outro traços da monstruosidade do imaginário medieval foi a primeira abordagem antropológica para o conhecimento, compreensão e entendimento dos novos humanos, à luz de todo o manancial cultural acumulado ao longo de séculos. Sereias, amazonas, gigantes, unicórnios, canibais, pessoas sem cabeça, pessoas com cauda, pessoas com enormes orelhas são alguns dos exemplos desse maravilhoso e fantástico imaginário projectado na nova realidade.

A monstruosidade do outro era a representação simbólica do pecado. A imagem do outro como monstro era a representação do outro sem alma, sem fé cristã. Toda a iconografia que proliferou no espaço colonial assumiu-se como tentativa de impor uma nova ordem visual e monopolizar a representação do sagrado, enquanto dispositivo de denominação simbólica e real, tentando alcançar a domesticação dos sentidos. Mas a discussão erudita sobre a origem e natureza do outro desenrola-se com base em argumentação 
teológica e bíblica e fundamentada em textos de autores clássicos. Contudo, todas as correntes convergiam em dois pontos: que todos os homens (do Novo e Velho mundos) descendiam de Adão e Eva e que os primeiros homens chegaram ao Novo Mundo após o Diluvio Universal.

A discussão em torno do "índio do ocidente" atingiu na época contornos políticos (do direito e da economia), para além da discussão antropológica. O indígena foi usado com finalidade política, mobilizando argumentos teológicos para justificar a legitimidade das possessões de Espanha no Novo Mundo. 